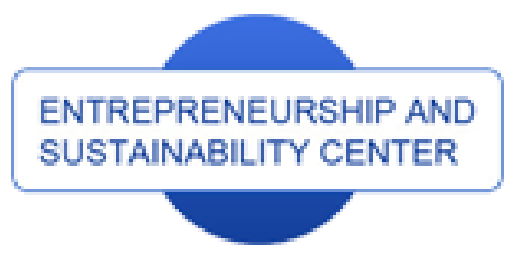

Publisher

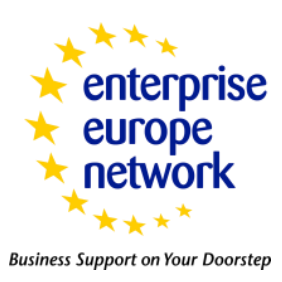

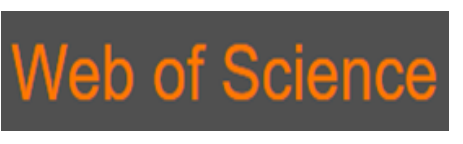

1 Clarivate Analytics

\title{
KNOWLEDGE MANAGEMENT PROCESS MODEL
}

\author{
Jurgita Raudeliūnienè1, Vida Davidavičienè2 ${ }^{2}$ Artūras Jakubavičius ${ }^{3}$
}

${ }^{1,2,3}$ Vilnius Gediminas Technical University, Sauletekio 11, Vilnius LT-10223, Lithuania

E-mails: ${ }^{1}$ jurgita.raudeliuniene@vgtu.lt; ${ }^{2}$ vida.davidaviciene@vgtu.lt; ${ }^{3}$ arturas.jakubavicius@vgtu.lt

Received 14 September 2017; accepted 20 January 2018; published 30 March 2018

\begin{abstract}
In the context of globalization and transformations, the knowledge potential management is an effective tool for increasing the effectiveness of organizations. The aim of the research is to study the procedural approach to the organization knowledge potential management, to distinguish the main knowledge management processes and to present suggestions on how to improve the knowledge management process model. The organization's knowledge potential in this study is defined, as the organization's resources and market opportunities, generating its knowledge potential, complexity and effective management of which create prerequisites for meeting the changing individual user needs, creating reciprocal value, uniqueness and leadership in the global marketplace. The conceptual knowledge management process model has been improved, based on the research. The first step in the model is the choice of a knowledge strategy, covering aspects of the formation and selection of strategic decision-making in knowledge potential management. The choice of an appropriate knowledge strategy brings to its implementation through a process of knowledge management cycle, consisting of knowledge acquisition, sharing, development, preservation and application of it. The knowledge management process model is completed with an evaluation of the knowledge strategy implementation.
\end{abstract}

Keywords: knowledge management, organization knowledge potential, knowledge management processes, procedural approach

Reference to this paper should be made as follows: Raudeliūnienė, J.; Davidavičienė, V.; Jakubavičius, A. 2018. Knowledge management process model, Entrepreneurship and Sustainability Issues 5(3): 542-554. https://doi.org/10.9770/jesi.2018.5.3(10)

JEL Classifications: M1, D8, D83.

\section{Introduction}

The society transformation into the knowledge society is changing user information and knowledge needs. The organizations, seeking to effectively meet changing user needs, are no longer equipped with knowledge, abilities and skills to manage traditional resources; there is also a need for effective organization knowledge potential management. How to efficiently manage the organization's knowledge potential in a dynamic and uncertain environment in the presence of limited organization resources for the sake of uniqueness and leadership in the market is a problem, investigated in the knowledge management discipline and realized through a process 
knowledge management cycle that creates preconditions for creating mutual value for both users and members of the organization.

The knowledge potential managing and evaluating aspects are relevant to improving the performance of organizations, but the age of information and knowledge is characterized by a dynamic environment; uncertainty is crucial to the uniqueness of organizations, where speed and quality become one of the key factors in effectively meeting the changing individual user needs. Organizations need to adapt quickly and efficiently to changing environmental conditions by effectively managing their knowledge potential. The poor decision-making and performance of knowledge potential management has negative consequences. Therefore, one of the key research objects in a dynamic and uncertain environment is how to integrate the organization knowledge potential.

The aim of the research is to investigate the procedural approach to the organization knowledge potential management, to distinguish the main knowledge management processes and to submit suggestions on how to improve the knowledge management process model. The knowledge management process model has been improved, based on integrated knowledge management model, studied by Probst, S. Raub, and K. Romhardt (2000) and consisting of eight processes: knowledge goals, identification, acquisition, development, distribution, preservation, use and measurement. The purpose of the research was to obtain scientific literature analysis, systematic analysis, comparative analysis, synthesis methods.

\section{The organization knowledge potential management concept}

Globalization, changes in the technological, social, cultural, economic, legal environment, transition from information to knowledge society affects not only user needs, changes in organizational management models in a dynamic and uncertain environment, but also changes in social sciences, when the analysis of the organizational advantages and risk management issues becomes complex, as well as integrated evaluation approaches and methods are needed to investigate it. For the organization's uniqueness and leadership in the global marketplace, it is important to know the specifics of managing and evaluating its knowledge potential (Alavi \& Leidner, 2001; Coyte, Ricceri, \& Guthrie, 2012; Fink, 2004, 2011; Firlej \& Żmija, 2017; Girish, Joseph, Roy, \& Raju, 2015; Huang, Quaddus, Rowe, \& Lai, 2011; Hunitie, 2017; Lin, 2014; Rathi, Given, \& Forcier, 2016; Saufi, Rusuli, Tasmin, \& Takala, 2012; Schwen, Kalman, Hara, \& Kisling, 1998; Starnawska, 2014; Stewart, 1997; Wong, 2005; Šafránková \& Šikýřr, 2017; Grenčiková et al., 2017).

The knowledge potential management and evaluation problem is discussed in the knowledge management discipline. Knowledge management is an emerging science discipline, integrating cognitive sciences, philosophy, sociology, psychology, information science, communication, document management, information management, information and communication technologies, management and economic theories, strategic management, change management, human resource management, organization learning, knowledge engineering, artificial intelligence and more (Fink, 2011; Kebede, 2010; Mciver \& Lepisto, 2017; Schwen et al., 1998; Raudeliūnienè \& MeidutèKavaliauskienè 2016; Rajnoha et al., 2017). Scientists provide a variety of knowledge management definitions (Alavi \& Leidner, 1999; Cheng \& Leong, 2017; Gao, Li, \& Clarke, 2008; García-Fernández, 2015; Kianto, Vanhala, \& Heilmann, 2016; Magnier-Watanabe \& Senoo, 2010; Massingham, 2014; Wiig, 2007; Yahya \& Goh, 2002).

Knowledge management is defined, as dynamic (García-Fernández, 2015) and a systematic process (Alavi \& Leidner, 1999; Wiig, 2007) or set of processes (Cheng \& Leong, 2017) for controlling knowledge workers (Gao et al., 2008), as knowledge management (Massingham, 2014) for gaining, organizing, communicating to accumulate, create, store, share, distribute and realize vague knowledge inside and outside of it (Alavi \& Leidner, 1999; García-Fernández, 2015; Kianto et al., 2016; Magnier-Watanabe \& Senoo, 2010), so that other employees 


\section{The International Journal}

ENTREPRENEURSHIP AND SUSTAINABILITY ISSUES

ISSN 2345-0282 (online) http://jssidoi.org/jesi/

2018 Volume 5 Number 3 (March)

http://doi.org/10.9770/jesi.2018.5.3(10)

can use it and be more efficient and productive at work (Alavi \& Leidner, 1999), more effective decision-making and adaptation in the market (Yahya \& Goh, 2002), more effective achievement of goals (Cheng \& Leong, 2017; Magnier-Watanabe \& Senoo, 2010).

Summarizing various scientific opinions, knowledge management is defined, as targeted and systematic management of processes, methods and tools, making full use of the organization's knowledge potential for strategic goals, making effective decisions, implementing and creating its value (Raudeliūnienè, 2017).

The knowledge potential concept is evaluated by scientists from different levels: individual, employee, organization, state (Bivainis \& Morkvėnas, 2010, 2012; Fink, 2004, 2011; Fink \& Roithmayr, 2005; Jang, Yang, \& Hong, 2014).

K. Fink et al. (2004, 2005, 2011) measure the knowledge potential by the knowledge prestige of the knowledge worker, his abilities, experience, gained through the learning process. Knowledge potential is seen, as identifying, distributing and implementing inaccurate knowledge for the strategic goals of the organization. The knowledge worker's knowledge potential includes user's capital, network and communication capability, competitor information, knowledge content and culture, learning and training processes, knowledge management systems, organization knowledge structure and assessment of inexperienced knowledge of experts. The key to knowledge management is to help a knowledge worker transform his knowledge potential into a visible organization. K. Fink et al. (2004, 2005, 2011) measure knowledge potential by the mass of knowledge (human factors), position (organizational and environmental factors) and speed (problem solving quality and speed) (Fink, 2004, 2011; Fink \& Roithmayr, 2005).

Through extensive research, related to the assessment of the organization's knowledge potential, J. Bivainis, R. Morkvenas $(2010,2012)$ argue that not only the definition of the organization's knowledge potential concept, but also the complex approach and evaluation methods, related to the assessment of the organization's knowledge potential, are absent. J. Bivainis, R. Morkvenas $(2010,2012)$ define the organization knowledge, as a whole, using the concept of knowledge potential, which includes both explicit and fuzzy knowledge and additional synergies, arising from the interaction of organizational elements (Bivainis \& Morkvenas, 2010, 2012).

J. Jang, J. Yang, and A. Hong (2014) value the knowledge potential through the mass of knowledge, the speed and position and the interaction between them, which influences the knowledge creation process. The scientists believe that the largest is the knowledge potential, the more knowledge is created (Jang et al., 2014).

The organization's knowledge potential in this study is defined, as the organization's resources and market opportunities, generating its knowledge potential, complexity and effective management of which create prerequisites for meeting the changing individual user needs for information and knowledge, creating reciprocal value, uniqueness and leadership in the marketplace.

\section{Process approach to managing organization knowledge potential}

How to efficiently manage knowledge potential in a dynamic environment under conditions of uncertainty, which management and evaluation problems are faced with risk reduction and the development and implementation of high-quality solutions - will be explored by integrating various insights from the scientists, related to the procedural approach to managing organization knowledge potential.

The scientists (Armistead, 1999; Becerra-Fernandez, Gonzalez, \& Sabherwal, 2004; Bigliardi, Galati, \& Petroni, 2014; Dalkir, 2011; Franco \& Mariano, 2007; García-Fernández, 2015; Kianto et al., 2016; Lin \& Lee, 2005; 
The International Journal

ENTREPRENEURSHIP AND SUSTAINABILITY ISSUES

ISSN 2345-0282 (online) http://jssidoi.org/jesi/

2018 Volume 5 Number 3 (March)

http://doi.org/10.9770/jesi.2018.5.3(10)

Lytras, Pouloudi, \& Poulymenakou, 2002; Nayır \& Uzunçarıl1, 2008; Nielsen, 2006; Pinho, Rego, \& Pina e Cunha, 2012; Probst, Raub, \& Romhardt, 2000; Rollett, 2003; Raudeliūnienė et al., 2016; Staab, Studer, Schnurr, \& Sure, 2001; Sun, 2010; Supyuenyong, Islam, \& Kulkarni, 2009; Wee \& Chua, 2013; Yusr, Mokhtar, Othman, \& Sulaiman, 2017) distinguish different combinations of knowledge management processes in approaching the knowledge management process (Table 1).

According to C. Armistead (1999), knowledge management processes are defined, as processes, knowledge is created, captured and codified, shared and transmitted, consolidated and used, measured and evaluated in. The scientist analyzed three key knowledge management processes: knowledge creation, knowledge transfer and knowledge embedding (Armistead, 1999).

G. Probst, S. Raub, K. Romhardt (2000) developed an integrated knowledge management system that includes such processes, as knowledge goals, identification, acquisition, development, distribution, preservation, use and measurement. In identifying knowledge, it is assessed, which essential competencies are necessary to achieve the organization goals. The knowledge identification process examines the knowledge gap to achieve the goals. In acquiring knowledge, decisions are made on how to eliminate knowledge gaps and to acquire the necessary competences. The knowledge development process involves the acquisition of new competences and new knowledge development. The knowledge dissemination and sharing process is aimed at sharing knowledge and ensuring access to knowledge-based activities. The essence of the knowledge process is the use of effective organization knowledge to achieve its goals. It is important to select, accumulate and update knowledge in preserving it in order to avoid the loss of valuable knowledge. The knowledge assessment examines the effectiveness of knowledge management activities and changes in the knowledge base (Probst et al., 2000).

S. Staab, R. Studer, H.-P. Schnurr, and Y. Sure (2001) presented ontology-based knowledge management approach and a knowledge management cycle, consisting of such processes, as: knowledge creation or import; capture; retrieval or access; and use (Staab et al., 2001).

M. D. Lytres, A. Pouloudi, A. Poulymenakou (2002) propose an advanced knowledge management process cycle, consisting of such processes, as: knowledge relate/value (identify, verify, filter, select); acquire (formalize, codify, represent, format, map); organize (store, transform); enable reuse (adapt, create); transfer (share, distribute, forward, link to people) and use (apply, integrate, learn) (Lytras et al., 2002).

H. Rollet (2003) investigated the following knowledge management processes: knowledge planning, creating knowledge, integrating knowledge, organizing knowledge, transfering knowledge, maintaining knowledge and assessing knowledge (Rollett, 2003).

I. Becerra-Fernandez, A. Gonzalez, R. Sabherwal (2004) integrated I. Nonaka (1994) (socialization, externalization, internalization, combination), R. M. Grant (1996), J. Nahapiet, S. Ghoshal (1998) (Grant, 1996; Nahapiet \& Ghoshal, 1998) empirical research results and distinguished four knowledge management processes: knowledge discovery, capture, sharing and application (Becerra-Fernandez et al., 2004).

H. F. Lin, G. G. Lee (2005) focused on the impact of learning opportunities (training available, technical expertise, and knowledge level) and knowledge acquisition (knowledge acquisition, knowledge application, and knowledge sharing) on e-business system adaptation. The research results showed that organizational learning factors and knowledge management processes are closely related to e-business system deployment level. However, the knowledge sharing process did not have a significant impact on e-business system deployment in the organisation (Lin \& Lee, 2005). 
The International Journal

ENTREPRENEURSHIP AND SUSTAINABILITY ISSUES

ISSN 2345-0282 (online) http://jssidoi.org/jesi/

2018 Volume 5 Number 3 (March)

http://doi.org/10.9770/jesi.2018.5.3(10)

A. P. Nielsen (2006) integrated knowledge management research into a dynamic capability approach, involving three knowledge management processes: knowledge development (acquisition, capture), knowledge (re)combination (assembly, sharing, integration) and knowledge use (leverage, exploitation) (Nielsen, 2006).

The purpose of the study by M. Franco, S. Mariano (2007) was to assess the impact of information technology repositories on knowledge management processes - knowledge storage and retrieval. The study found that factors affect the knowledge retrieval process from the perspective of information technology repositories and that the storage process was related to three different events, occurring before, during and after the repository delivery to the organization (Franco \& Mariano, 2007).

D. Z. Nayır, U. Uzunçarşılı (2008) analyzed how effective knowledge management practices together with a unique business culture allowed the organization to become extremely successful; in his research, he investigated three knowledge management processes: knowledge acquisition, knowledge sharing and knowledge utilization (Nayır \& Uzunçarıl1, 2008).

V. Supyuenyong, N. Islam, U. Kulkarni (2009) analyzed how the knowledge management process affects the knowledge management process: knowledge and process creation; knowledge organization and retention; knowledge dissemination; knowledge utilization. The research results showed that the ownership and management structure, cultural and behavioral characteristics have a positive effect in comparison with other analyzed characteristics for knowledge management processes. Systems, processes and procedures, user and market features have more, than an average impact. Human capital management, rather interferes with, than facilitates knowledge management processes (Supyuenyong et al., 2009).

P. Sun (2010) analyzed how the organization's routine affects knowledge management processes: knowledge acquisition; knowledge creation; knowledge utilization and sharing. Knowledge acquisition involves processes, knowledge is acquired in from external sources; knowledge creation is the transformation of newly acquired knowledge into the context of an organization, and the application of knowledge and sharing of it is the constant use of newly created knowledge and sharing of it between individuals or groups (Sun, 2010).

K. Dalkir (2011) integrated empirical research results (Bukowitz \& Williams, 2000; Mcelroy, 1999; Meyer \& Zack, 1996; Rollett, 2003; Wiig, 1993) and distinguished the following knowledge management processes: knowledge capture and codification, knowledge sharing and dissemination, knowledge acquisition and application (Dalkir, 2011).

I. Pinho, A. Rego, M. Pina e Cunha (2012) identifies barriers and opportunities (through technological, social, organizational and individual prism) for the following four knowledge management processes: knowledge acquisition, creation, sharing, and transfer (Pinho et al., 2012).

J. C. N. Wee, A. Y. K. Chua (2013) examined the peculiarities of the following three knowledge management processes that are unique to small and medium-sized organizations: knowledge creation, knowledge sharing amd knowledge reuse. The research results showed that knowledge creation is innovative individual solutions for meeting the needs of users; knowledge sharing takes place through cross-functionality, matching roles and facilitates this process through close physical closeness to open workplaces; knowledge reuse is often performed in an unrepresentative form, where general knowledge is most often included in processes (Wee \& Chua, 2013). 
Table 1. The spectrum of knowledge management processes

\begin{tabular}{|c|c|c|c|c|c|c|c|c|c|c|c|c|}
\hline $\begin{array}{c}\text { Author, } \\
\text { year/ Process }\end{array}$ & 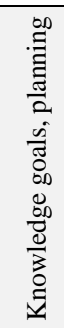 & 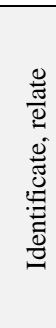 & 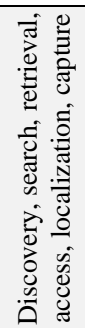 & 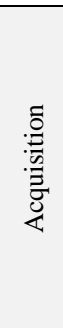 & 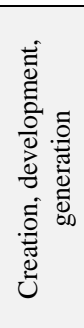 & 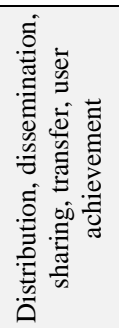 & 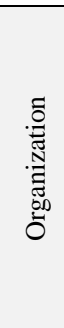 & 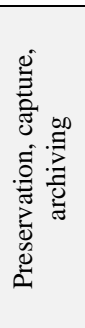 & 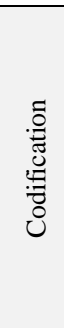 & 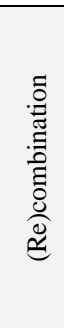 & 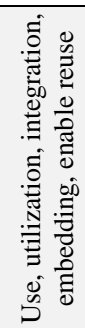 & 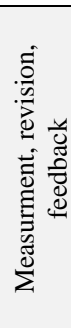 \\
\hline $\begin{array}{l}\text { Armistead } \\
1999\end{array}$ & & & & & + & + & & & & & + & \\
\hline $\begin{array}{l}\text { Probst et al. } \\
2000\end{array}$ & + & + & & + & + & + & & + & & & + & + \\
\hline $\begin{array}{l}\text { Staab et al. } \\
2001\end{array}$ & & & $+/+$ & & + & & & & & & + & \\
\hline $\begin{array}{l}\text { Lytras et al. } \\
2002\end{array}$ & & + & & + & & + & + & & & & $+/+$ & \\
\hline Rollet 2003 & + & & & & + & + & & + & & & + & + \\
\hline $\begin{array}{l}\text { Becerra- } \\
\text { Fernandez et } \\
\text { al. } 2004\end{array}$ & & + & + & & & + & & & & & + & \\
\hline Lin et al. 2005 & & & & + & & + & & & & & + & \\
\hline Nielsen 2006 & & & & & + & & & & & + & + & \\
\hline $\begin{array}{l}\text { Franco et al. } \\
2007\end{array}$ & & & + & & & & & + & & & & \\
\hline $\begin{array}{l}\text { Nayir et al. } \\
2008\end{array}$ & & & & + & & + & & & & & + & \\
\hline $\begin{array}{l}\text { Supyuenyong } \\
\text { et al. } 2009\end{array}$ & & & & + & + & + & + & + & & & + & \\
\hline Sun 2010 & & & & + & + & + & & & & & + & \\
\hline Dalkir 2011 & & & + & + & + & + & & & & & + & \\
\hline $\begin{array}{l}\text { Pinho et al. } \\
2012\end{array}$ & & & & + & + & $+/+$ & & & & & & \\
\hline $\begin{array}{l}\text { Wee et al. } \\
2013\end{array}$ & & & & & + & + & & & & & + & \\
\hline $\begin{array}{l}\text { Bigliardi et al. } \\
2014 \\
\text { García- }\end{array}$ & & & & & + & + & & + & & & & + \\
\hline $\begin{array}{l}\text { Fernández } \\
2015\end{array}$ & & & & & + & + & & + & & & + & \\
\hline $\begin{array}{l}\text { Kianto et al. } \\
2016\end{array}$ & & & & + & + & + & & + & + & & & \\
\hline $\begin{array}{l}\text { Yusr et al. } \\
2017\end{array}$ & & & & + & & + & & & & & + & \\
\hline
\end{tabular}

Source: created by Authors

Research of B. Bigliardi, F. Galati, A. Petroni (2014) confirmed that there is no general and unique knowledge management system in the organizations examined. This means that the examined organizations apply different knowledge management processes about the specifics of the activities carried out. The researchers highlighted two basic similarities among the 14 organizations surveyed: knowledge management process is cyclical in all organizations; the organizations investigated apply the following key knowledge management processes: (1) 
The International Journal

ENTREPRENEURSHIP AND SUSTAINABILITY ISSUES

ISSN 2345-0282 (online) http://jssidoi.org/jesi/

2018 Volume 5 Number 3 (March)

http://doi.org/10.9770/jesi.2018.5.3(10)

creation, search and capture of knowledge; (2) organization, storage and preservation of knowledge; (3) distribution, transfer and sharing of knowledge; (4) feedback stage (Bigliardi et al., 2014).

Based on 78 sources, M. García-Fernández (2015) analyzed knowledge management processes and highlighted these processes and their factors that were most often investigated by researchers: knowledge creation (acquisition of information, information dissemination, shared understanding), knowledge transfer and storage (knowledge storage, knowledge transfer in the organization, application and use of knowledge (teamwork, empowerment, commitment to knowledge) (García-Fernández, 2015).

A. Kianto, M. Vanhala ir P. Heilmann (2016) analyzed the following five knowledge management processes: knowledge acquisition, sharing, creation, codification and retention. Knowledge creation means the organization's ability to create new and useful ideas and solutions, related to the various aspects of organizational activity, from products and technological processes to management practices. Knowledge codification consists of the activities, necessary to transform the inexpressible knowledge into expressive knowledge, to preserve formalized knowledge and to provide the latest registered knowledge to the organization employees. The effectiveness of this process depends on the competence and motivation of the employees and the information and communication technology infrastructure. Knowledge preservation relates to the management of human resources in order to reduce the loss of expertise in the organization (Kianto et al., 2016).

M. M. Yusr, S. S. M. Mokhtar, A. R. Othman, Y. Sulaiman (2017) distinguished the following three knowledge management processes that influence innovation: knowledge acquisition, knowledge dissemination and knowledge application. According to the scientists, these knowledge management processes (the process of gaining valuable knowledge, disseminating this knowledge in the organization, timely delivery and commercial application) are important in order to improve the organization's innovative results (Yusr et al., 2017).

Summarizing the knowledge management processes, studied by Armistead, 1999; Becerra-Fernandez, Gonzalez, \& Sabherwal, 2004; Bigliardi, Galati \& Petroni, 2014; Dalkir, 2011; Franco \& Mariano, 2007; García-Fernández, 2015; Kianto et al., 2016; HF Lin \& Lee, 2005, Lytras, Pouloudi, \& Poulymenakou, 2002; Nayır \& Uzunçarıl1, 2008; Nielsen, 2006; Pinho, Rego, \& Pina e Cunha, 2012, Probst, Raub, \& Romhardt, 2000; Rollett, 2003; Staab, Studer, Schnurr, \& Sure, 2001; Sun, 2010; Supyuenyong, Islam, \& Kulkarni, 2009; Wee \& Chua, 2013; Yusr, Mokhtar, Othman, \& Sulaiman, 2017, it was found that most scientists are investigating such essential knowledge management processes, as (Fig. 1):

- (1) knowledge distribution, dissemination, sharing, transfer, user achievement (27 per.);

- (2) knowledge use, utilization, integration, embedding, enable reuse (25.4 per.);

- (3) knowledge creation, development, generation (20.6 per.);

- (4) knowledge acquisition (15.9 per.);

- (5) knowledge preservation, capture, archiving (11.1 per.).

The scientific literature analysis has shown that knowledge management processes, studied by most scientists, do not have a clear knowledge management structure and feedback aspects, important in assessing the model of knowledge management process, involving the process cycle beginning and stages of its completion.

According to García-Fernández (2015), several studies have been conducted on knowledge management processes from a different perspective, but it is difficult to identify and measure knowledge management processes because there is no consensus on the dimensions of the assessment of knowledge management processes, which necessitates the creation of an integrated knowledge management model (García-Fernández, 2015). 


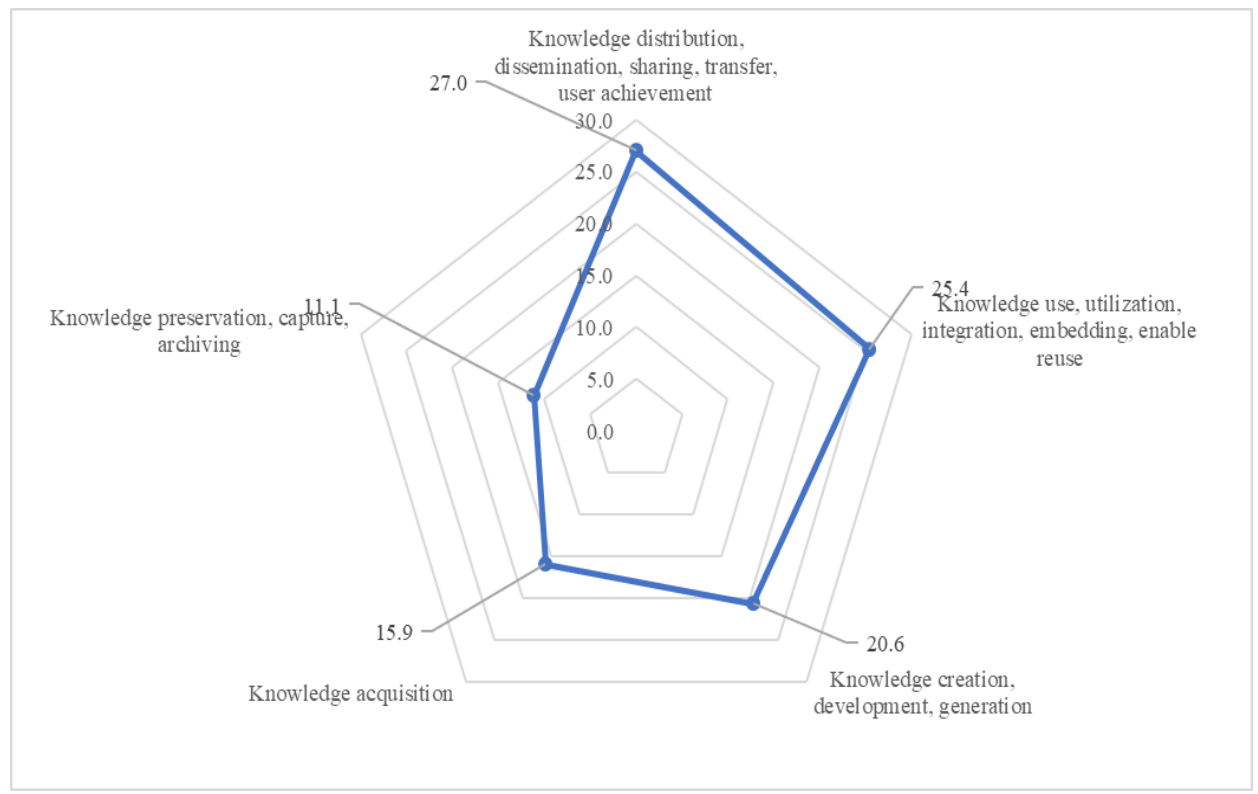

Fig. 1. Distribution of knowledge management processes (per.)

Source: created by Authors

For these reasons, for further research purposes, to improve the knowledge management process model, knowledge management cycle of Probst, S. Raub, and K. Romhardt (2000) has been chosen for the development of a more structured and advanced knowledge management structure, from the identification, acquisition, development, sharing and dissemination of knowledge objectives, application, preservation and knowledge assessment.

\section{Aspects of improving the knowledge management model}

Globalization, technological advancement challenges, environmental dynamics, changes in public knowledge needs and behaviors and the associated transformation from the information society to the knowledge society, structural changes in organizational management shape the need for a comprehensive knowledge strategy development and implementation through a process knowledge management model.

Based on the research, based on an integrated knowledge management system, proposed by Probst, S. Raub, and K. Romhardt (2000), which includes eight knowledge management processes - knowledge goals, identification, acquisition, development, distribution, preservation, use and measurement - , the defects of the model were identified in relation to the knowledge strategy formation, process consistency and complexity assessment aspects.

The main problem of the integrated knowledge management system, proposed by Probst, S. Raub, K. Romhardt (2000), is the formation of a knowledge strategy that must be implemented through process knowledge management. The model of Probst, S. Raub, and K. Romhardt (2000) offer two successive stages - knowledge goals and identification. At the beginning, the knowledge goals are set, then the knowledge-based process is passed, which focuses on assessing, which competences (knowledge, skills) are lacking in achieving the goals. In this case, the methods and tools, based on the formation of knowledge goals, are lost, and the following question 
arises: how an organization, which did not evaluate its position on the outside and the available internal resources, can qualitatively formulate the strategic knowledge potential management goals.

The integrated knowledge management system, proposed by Probst, S. Raub, and K. Rahnardt (2000), identifies the shortcomings, related to process consistency, as the knowledge retention process in the model takes place after the process of applying knowledge. Then the question arises on how to apply the organization knowledge, if it is not saved. To solve this problem, it is proposed to complete the knowledge preservation process by acquiring, sharing and creating knowledge in the organization.

The integrated knowledge management system, proposed by Probst, S. Raub, and K. Romhardt (2000), lacks complex approaches and evaluation methods for analyzing organizational knowledge management processes in a dynamic environment, there is a constant change and the associated uncertainty in. Therefore, to formulate highquality strategic decision-making on managing knowledge potential, the complex task of the organization's external and internal factors and the search of methods, which help to analyze the problem areas of the knowledge management process and seek ways to eliminate them, becomes an important task.

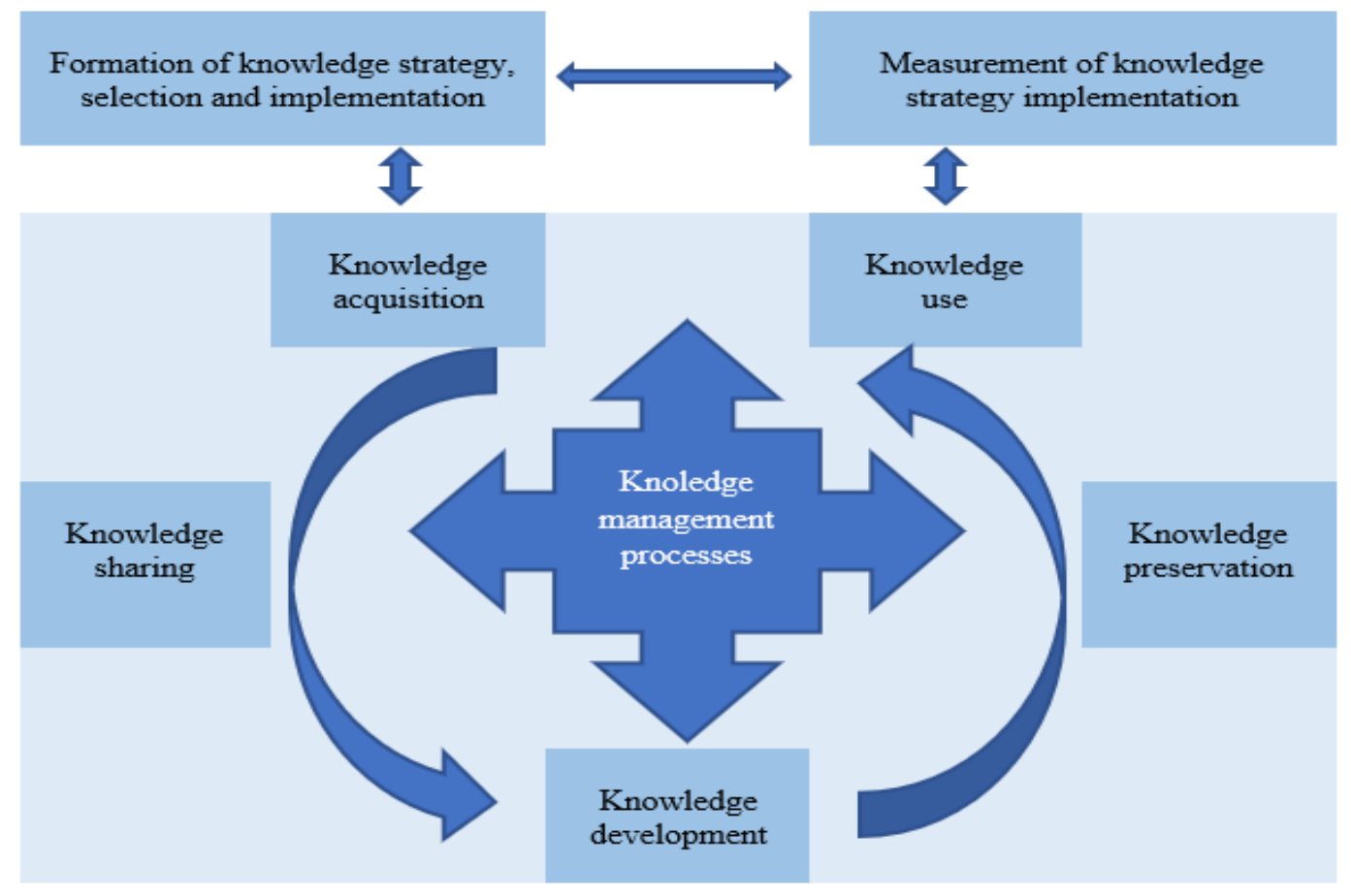

Fig. 2. Improved conceptual knowledge management process model

Source: created by Authors (according Probst et al., 2000; Raudeliūnienè, 2017)

Regarding the shortcomings, identified in the integrated knowledge management system of Probst, S. Raub and $\mathrm{K}$. Romhardt (2000), it is proposed to improve the knowledge management process model from the choice of knowledge strategy - formation, selection and management of strategic decision-making in knowledge potential management through the knowledge management process, consisting of knowledge acquisition, sharing, development, preservation and application. The knowledge management process model is completed with an evaluation of the knowledge strategy implementation (Fig. 2). 
The International Journal

ENTREPRENEURSHIP AND SUSTAINABILITY ISSUES

ISSN 2345-0282 (online) http://jssidoi.org/jesi/

2018 Volume 5 Number 3 (March)

http://doi.org/10.9770/jesi.2018.5.3(10)

The external and internal factors, affecting knowledge potential, are evaluated during the formation, selection and implementation of the knowledge strategy. The strengths and weaknesses identified, based on the research results, identifying the organization's position in the market and choosing a knowledge strategy, which forms the basis of the strategic decision-making process for the knowledge strategy implementation through a process knowledge management model.

\section{Conclusions}

The conceptual knowledge management process model has been improved, based on the research. The following general conclusions and recommendations are formulated in the development of the model.

In the context of transformations, the knowledge potential management is an effective tool for improving the efficiency of organizations. Effective organization knowledge potential management influences the entire organization's knowledge creation value chain by creating the preconditions for finding out the changing needs of the user and for the purposeful development of the organization's knowledge potential to meet the needs to create a reciprocal value, i. e. through the perception of individual needs of users to form unique solutions, implementation of which creates value for the user through satisfaction of needs and communication, for the organization loyalty, uniqueness and leadership.

The organization's knowledge potential in this study is defined, as the organization's resources and market opportunities, generating its knowledge potential, complexity and effective management of which create prerequisites for meeting the changing individual user needs, creating reciprocal value, uniqueness and leadership in the global marketplace.

The process knowledge management model, proposed by the organization to manage the knowledge potential, forms a process cycle and the knowledge creation value chain. Scientific literature presents different approaches to knowledge management processes and their range. The scientific literature analysis revealed that scientists are most often researching the processes of knowledge sharing, application, development (creation), acquisition and preservation. However, the knowledge management processes, analyzed by the scientists, do not have clear knowledge of the course, sequence, structure and feedback aspects of knowledge management, which is important in assessing the knowledge management process model, involving the start of the process cycle and its completion. The assessment of knowledge management processes is based on different approaches; therefore, it is difficult to measure knowledge management processes and, as a result, there is a need to develop an integrated knowledge management model. For these reasons, the integrated knowledge management cycle of G. Probst, S. Raub, K. Romhardt (2000) on the identification of the knowledge management progression, starting with the identification of knowledge goals, was chosen for further research and improvement of the knowledge management process model, acquisition, creation, sharing and distribution, application, preservation and evaluation.

After examining the integrated knowledge management system, developed by G. Probst, S. Raub, K. Romhardt (2000), the shortcomings of this model were identified with the formation of knowledge strategy, process coherence and complexity assessment aspects. Regarding the shortcomings, identified in the integrated knowledge management system of G. Probst et al. (2000), it is proposed to improve the conceptual knowledge management process model from the choice of knowledge strategy - formation, selection and management of strategic decision-making in knowledge potential management through the knowledge management process, consisting of knowledge acquisition, sharing, development, preservation and application. The knowledge management process model is completed with an evaluation of the knowledge strategy implementation. 


\section{The International Journal}

ENTREPRENEURSHIP AND SUSTAINABILITY ISSUES

ISSN 2345-0282 (online) http://jssidoi.org/jesi/

2018 Volume 5 Number 3 (March)

http://doi.org/10.9770/jesi.2018.5.3(10)

Further research trends could be linked to the assessment of the relationship between knowledge management process model variables and their impact on the effective knowledge potential management and the effectiveness of the organization's activities.

\section{References}

Alavi, M., \& Leidner, D. E. (1999). Knowledge management systems: issues, challenges, and benefits. Communications of the AIS, 1(7), $1-37$.

Alavi, M., \& Leidner, D. E. (2001). Review: knowledge management and knowledge management systems: conceptual foundations and research issues. MIS Quarterly, 25(1), 107-136. http://www.jstor.org/stable/3250961

Armistead, C. (1999). Knowledge management and process performance. Journal of Knowledge Management, 3(2), $143-157$. https://doi.org/10.1108/13673279910275602

Becerra-Fernandez, I., Gonzalez, A., \& Sabherwal, R. (2004). Knowledge management: challenges, solutions, and technologies. N.J.: Pearson Prentice Hall.

Bigliardi, B., Galati, F., \& Petroni, A. (2014). How to effectively manage knowledge in the construction industry. Measuring Business Excellence, 18(3), 57-72. https://doi.org/10.1108/MBE-10-2013-0055

Bivainis, J., \& Morkvenas, R. (2010). Quantitative model of organization's knowledge potential assessment. In The 6th International Scientific Conference “Business and Management 2010”, Selected papers (pp. 586-594). Vilnius, Lithuania.

Bivainis, J., \& Morkvėnas, R. (2012). Integrated assessment of organization's knowledge potential. Journal of Business Economics and Management, 13(1), 81-94. https://doi.org/10.3846/16111699.2011.620152

Bukowitz, W. R., \& Williams, R. L. (2000). The knowledge management fieldbook. London: Financial Times Prentice Hall.

Cheng, L., \& Leong, S. (2017). Knowledge management ecological approach: a cross-discipline case study. Journal of Knowledge Management, 21(4), 839-856. https://doi.org/10.1108/JKM-11-2016-0492

Coyte, R., Ricceri, F., \& Guthrie, J. (2012). The management of knowledge resources in SMEs: an Australian case study. Journal of Knowledge Management, 16(5), 789-807. https://doi.org/10.1108/13673271211262817

Dalkir, K. (2011). Knowledge Management in Theory and Practice. (MIT Press, Ed.). Cambridge.

Fink, K. (2004). Knowledge Potential Measurement and Uncertainty. Deutscher Universitätsverlag.

Fink, K. (2011). Process model for knowledge potential measurement in SMEs. In Strategies for Knowledge Management Success: Exploring Organizational Efficacy (pp. 91-105). New York: Information Science Reference.

Fink, K., \& Roithmayr, F. (2005). Knowledge potential measurement - theoretical framework and case studies. In Knowledge Management Nurturing Culture, Innovation, and Technology (pp. 571-582). https://doi.org/10.1142/9789812701527 0050

Firlej, K., \& Żmija, D. (2017). The specificity of knowledge management in the food industry in Poland. E\&M Economics and Management, 20(1), 83-97. https://doi.org/10.15240/tul/001/2017-1-006

Franco, M., \& Mariano, S. (2007). Information technology repositories and knowledge management processes: A qualitative analysis. VINE, 37(4), 440-451. https://doi.org/10.1108/03055720710838515

Gao, F., Li, M., \& Clarke, S. (2008). Knowledge, management, and knowledge management in business operations. Journal of Knowledge Management, 12(2), 3-17. https://doi.org/10.1108/13673270810859479

García-Fernández, M. (2015). How to measure knowledge management: dimensions and model. VINE, 45(1), 107-125. https://doi.org/10.1108/VINE-10-2013-0063

Girish, G. P., Joseph, D., Roy, S., \& Raju, G. A. (2015). Factors influencing adoption of knowledge management systems in India from a micro, small and medium enterprise's perspective. International Review of Management and Marketing, 5(53), 135-140.

Grant, R. M. (1996). Toward a knowledge-based view of the firm. Strategic Management Journal. https://doi.org/10.2307/2486994

Grenčiková, A.; Guščinskienè, J.; Španková, J. 2017. The role of leadership in motivating employees in a trading company, Journal of Security and Sustainability Issues 7(2): 247-255. https://doi.org/10.9770/jssi.2017.7.2(6)

Huang, L. S., Quaddus, M., Rowe, A. L., \& Lai, C. P. (2011). An investigation into the factors affecting knowledge management adoption and practice in the life insurance business. Knowledge Management Research \& Practice, 9, 58-72. https://doi.org/10.1057/kmrp.2011.2

Hunitie, M. (2017). Factors affecting knowledge management adoption in public organizations. International Journal of Advanced and Applied Sciences, 4(1), 40-46. https://doi.org/10.21833/ijaas.2017.01.006

Jang, J., Yang, J., \& Hong, A. (2014). Measurement of knowledge potential in the ICT service industry: a quantum mechanics view. In Proceedings of the 11th International Conference on Intellectual Capital, Knowledge Management and Organisational Learning (pp. 248-258).

Kebede, G. (2010). Knowledge management: An information science perspective. International Journal of Information Management, 30(5), 416-424. https://doi.org/10.1016/j.ijinfomgt.2010.02.004

Kianto, A., Vanhala, M., \& Heilmann, P. (2016). The impact of knowledge management on job satisfaction. Journal of Knowledge Management, 20(4), 621-636. https://doi.org/10.1108/JKM-10-2015-0398 


\section{The International Journal}

ENTREPRENEURSHIP AND SUSTAINABILITY ISSUES

ISSN 2345-0282 (online) http://jssidoi.org/jesi/

2018 Volume 5 Number 3 (March)

http://doi.org/10.9770/jesi.2018.5.3(10)

Lin, H.-F. (2014). Contextual factors affecting knowledge management diffusion in SMEs. Industrial Management \& Data Systems, 114(9), 1415-1437. https://doi.org/10.1108/IMDS-08-2014-0232

Lin, H. F., \& Lee, G. G. (2005). Impact of organizational learning and knowledge management factors on e-business adoption. Management Decision, 43(2), 171-188. https://doi.org/10.1108/00251740510581902

Lytras, M. D., Pouloudi, A., \& Poulymenakou, A. (2002). Knowledge management convergence - expanding learning frontiers. Journal of Knowledge Management, 6(1), 40-51. https://doi.org/10.1108/13673270210417682

Magnier-Watanabe, R., \& Senoo, D. (2010). Shaping knowledge management: organization and national culture. Journal of Knowledge Management, 14(2), 214-227. https://doi.org/10.1108/13673271011032364

Massingham, P. (2014). An evaluation of knowledge management tools: Part 1 - managing knowledge resources. Journal of Knowledge Management, 18(6), 1075-1100. https://doi.org/10.1108/JKM-11-2013-0449

Mcelroy, M. W. (1999). The Knowledge Life Cycle An Executable Model For The Enterprise. Miami, FL.

Mciver, D., \& Lepisto, D. A. (2017). Effects of knowledge management on unit performance: examining the moderating role of tacitness and learnability. Journal of Knowledge Management, 21(4), 796-816. https://doi.org/10.1108/JKM-08-2016-0347

Meyer, M. H., \& Zack, M. H. (1996). The design and development of information products. Sloan Management Review, 37(3), 43-59.

Nahapiet, J., \& Ghoshal, S. (1998). Social capital, intellectual capital, and the organizational advantage. Academy of Management Review, 23(2), 242-266.

Nayır, D. Z., \& Uzunçarılı, U. (2008). A cultural perspective on knowledge management: the success story of Sarkuysan company. Journal of Knowledge Management, 12(2), 141-155. https://doi.org/10.1108/13673270810859578

Nielsen, A. P. (2006). Understanding dynamic capabilities through knowledge management. Journal of Knowledge Management, 10(4), 59-71. https://doi.org/10.1108/13673270610679363

Pinho, I., Rego, A., \& Pina e Cunha, M. (2012). Improving knowledge management processes: a hybrid positive approach. Journal of Knowledge Management, 16(2), 215-242. https://doi.org/10.1108/13673271211218834

Probst, G., Raub, S., \& Romhardt, K. (2000). Managing knowledge: building blocks for success. John Wiley \& Sons.

Rathi, D., Given, L. M., \& Forcier, E. (2016). Knowledge needs in the non-profit sector: an evidence-based model of organizational practices. Journal of Knowledge Management, 20(1), 23-48. https://doi.org/10.1108/JKM-12-2014-0512

Rajnoha, R.; Korauš, A.; Dobrovič, J. 2017. Information systems for sustainable performance of organizations, Journal of Security and Sustainability Issues 7(1): 167-179. https://doi.org/10.9770/jssi.2017.7.1(14)

Raudeliūnienè, J.; Meidute-Kavaliauskiene, I. 2016. Editorial, International Journal of Learning and Change. Special issue on knowledge management: theory and practice in SMEs, 8(3/4): 193-197. Available on internet: http://www.inderscience.com/info/inarticletoc.php?.jcode=ijlc \&year=2016\&vol=8\&issue=3/4

Raudeliūnienè, J.; Meidutè-Kavaliauskienė, I.; Vileikis K. 2016. Evaluation of factors determining the efficiency of knowledge sharing process. Journal of The Knowledge Economy 7(4): 842-857. https://doi.org/10.1007/s13132-015-0257-4

Raudeliūnienè, J. (2017). Organizacijos žiniu potencialo vertinimo aktualijos [Topicalities of the organization's knowledge potential assessment]. Vilnius: Technika.https://doi.org/10.20334/2017-065-M

Rollett, H. (2003). Knowledge management: processes and technologies. Boston: Kluwer Academic Publishers.

Saufi, M., Rusuli, C., Tasmin, R., \& Takala, J. (2012). Knowledge record and knowledge preservation: a conceptual framework of Malaysian university libraries. International Journal of Information Technology and Business Management, 3(1), 30-37.

Schwen, T. M., Kalman, H. K., Hara, N., \& Kisling, E. L. (1998). Potential knowledge management contributions to human performance technology research and practice. ETR\&D, 46(4), 73-89.

Staab, S., Studer, R., Schnurr, H.-P., \& Sure, Y. (2001). Knowledge processes and ontologies. IEEE Intelligent Systems, 16(1), $26-34$.

Starnawska, M. (2014). Knowledge management in SMEs - selected issues. In In Development of enterprises' competitiveness in the context of demographic challenges/ Ed. Grzesiak, M.; Richert-Kazmierska, A. (pp. 305-314). Hamburg: Baltic Sea Academy.

Stewart, T. A. (1997). Intellectual Capital: The New Wealth of Organizations (1st ed.). New York: Doubleday.

Sun, P. (2010). Five critical knowledge management organizational themes. Journal of Knowledge Management, 14(4), 507-523. https://doi.org/10.1108/13673271011059491

Supyuenyong, V., Islam, N., \& Kulkarni, U. (2009). Influence of SME characteristics on knowledge management processes: The case study of enterprise resource planning service providers. Journal of Enterprise Information Management, 22(1/2), 63-80. https://doi.org/10.1108/17410390910922831

Šafránková, J. M.; Šikýř, M. 2017. Sustainable development of the professional competencies of university students: comparison of two selected cases from the Czech Republic, Journal of Security and Sustainability Issues7(2): 321333. https://doi.org/10.9770/jssi.2017.7.2(12)

Wee, J. C. N., \& Chua, A. Y. K. (2013). The peculiarities of knowledge management processes in SMEs: the case of Singapore. Journal of Knowledge Management, 17(6), 958-972. https://doi.org/10.1108/JKM-04-2013-0163

Wiig, K. M. (1993). Knowledge Management Foundations: Thinking about Thinking - how People and Organizations Represent, Create, and Use Knowledge. Arlington: TX: Schema Press.

Wiig, K. M. (2007). Effective societal knowledge management. Journal of Knowledge Management, 11(5), 141-156. https://doi.org/10.1108/13673270710819861

Wong, K. Y. (2005). Critical success factors for implementing knowledge management in small and medium enterprises. Industrial 
The International Journal
ENTREPRENEURSHIP AND SUSTAINABILITY ISSUES

ISSN 2345-0282 (online) http://jssidoi.org/jesi/

2018 Volume 5 Number 3 (March)

http://doi.org/10.9770/jesi.2018.5.3(10)

Management \& Data Systems, 105(3), 261-279. https://doi.org/10.1108/02635570510590101

Yahya, S., \& Goh, W. K. (2002). Managing human resources toward achieving knowledge management. Journal of Knowledge Management, 6(5), 457-468. https://doi.org/10.1108/13673270210450414

Yusr, M. M., Mokhtar, S. S. M., Othman, A. R., \& Sulaiman, Y. (2017). Does interaction between TQM practices and knowledge management processes enhance the innovation performance? International Journal of Quality \& Reliability Management, 34(7), 955-974. https://doi.org/10.1108/IJQRM-09-2014-0138

Jurgita RAUDELIŪNIENĖ is a doctor of social sciences (Management), Professor at Vilnius Gediminas Technical University (VGTU), Faculty of Business Management. Her research interests are related to knowledge management, formation and evaluation of strategic decisions, sustainable development. She has developed several monographs and textbooks in knowledge management area, published more than 50 research papers in scientific journals, actively involved in studies and research projects (Head of VGTU part in projects "Design Lab" (2017-2019), Tempus IV MATRE (2013-2017), researcher in Horizon 2020 (H2020-MSCA-RISE-2014) Cluster Development Med and etc.), member of the scientific and organising committee in international scientific conferences, editorial board member of international scientific journals. She is an expert of Lithuania and Poland Research Councils.

ORCID ID: orcid.org/0000-0003-4003-0856

Vida DAVIDAVIČIENĖ head of Department of Business Technologies and Entrepreneurship at Vilnius Gedimintas Technical University (VGTU). Throughout her career she has been involved as an expert or researcher in EU and Lithuanian projects (Framework 5th, Leonardo da Vinci, TEMPUS, ERASMUS, etc.), and as such gained solid knowledge and experience in development knowledge transfer skills by employing ICT. Her research interests are ICT development influence on society, business, and economics (e. business, e. marketing, e. logistic, e. government, e. behaviour, smart cities, and innovative ICT solutions). Prof. dr. Vida Davidavičienè is an author of more than 70 scientific publications indexed in Web of Science, Scopus, Ebsco, Emerald and other databases, published 1 course book, 2 text books, 7 book (monograph) parts. She is a member of the scientific comities of several scientific journals, and international scientific conferences. She is member of management science board in VGTU.

ORCID ID: orcid.org/0000-0002-0931-0967

Artūras JAKUBAVIČIUS is a doctor of Social Sciences (Management) at Vilnius Gediminas Technical University (VGTU), Faculty of Business Management as well as a Manager of Innovation Support Services at the Lithuania Innovation Centre. His research interests are in a field of knowledge and innovation management with an interest in formation and evaluation of innovation systems and strategic decisions and innovation support services. During his career prof. Jakubavičius published over forty research papers, several monographs and textbooks on innovation and knowledge management. Being actively involved in studies and research projects he continuously acted as a head or researcher/expert in over thirty Research \& Development as well as innovation support projects financed by Horizon 2020, FP7, INTERREG and other programmes. A member of expert boards and councils related to development and evaluation of R\&D and innovation support system in Lithuania. He is a long-standing expert of the Lithuania national award committee - "Innovation Prise".

ORCID ID: orcid.org/0000-0001-7936-5931

Copyright (C) 2018 by author(s) and VsI Entrepreneurship and Sustainability Center

This work is licensed under the Creative Commons Attribution International License (CC BY).

http://creativecommons.org/licenses/by/4.0/

cC) (7) Open Access 